\title{
LA CAPILLA MUSICAL DE LA IGLESIA DE SANTA MARÍA DEL JUNCAL EN IRÚN (1780-1860)
}

\section{THE MUSIC CHAPEL OF SANTA MARÍA DEL JUNCAL CHURCH, IRÚN, $1780-1860$}

\author{
Paulino Capdepón Verdú \\ Universidad de Castilla-La Mancha
}

\begin{abstract}
Resumen:
Hasta época bien reciente la música en la ciudad guipuzcoana de Irún apenas había llamado la atención de los investigadores. Sin embargo, en los últimos tiempos diferentes estudios han demostrado la importancia musical que desempeñó la citada ciudad española. En este artículo se aborda por primera vez el estudio de la capilla musical de la Iglesia de Santa María del Juncal, principal institución eclesiástica de Irún, desde finales del siglo XVIII hasta 1860, teniendo en cuenta su composición, las principales festividades según el calendario litúrgico, funciones de los distintos componentes musicales de la capilla, etc. así como la trayectoria de los primeros maestros de capilla-organistas que ejercieron dicho cargo entre 1780 y 1860, entre los que destacan Miguel de Balzola, Agustín Cayetano de Echaide y Juan Antonio Prol.
\end{abstract}

Palabras clave:

Irún. Siglo XIX. Santa María del Juncal. Capilla de música. Reglamento de música. Maestro de capilla-organista.

\begin{abstract}
:
Until recent times the music in the city of Irún (Guipúzcoa) drew hardly the interest of researchers. However, different studies have demonstrated in recent years the importance played by music in this Spanish city. This article first focus on the study of the music chapel at the Church of Santa Maria del Juncal, principal ecclesiastical institution in Irún, since the end of 18th century until 1860, taking into account its composition, the main festivities according to the liturgical calendar, functions of the musical components of the music chapel, etc. and the background of the chapel masters-organists who have held this position between 1780 and 1860, among which stand out Miguel de Balzola, Agustín Cayetano de Echaide and Juan Antonio Prol.
\end{abstract}

Key words:

Irún. 19th century. Santa María del Juncal. Music Chapel. Music Regulations. Chapel Master-Organist. 


\section{INTRODUCCIÓN}

La situación fronteriza de Irún ha determinado la importancia estratégica de esta ciudad en la época moderna: así por ejemplo, en Irún acaeció la Primera Batalla de San Marcial entre el ejército español y el francés el 30 de junio de 1522, que se saldó con la victoria de las armas españolas: dicha victoria dará lugar a la principal festividad cívico-religiosa de Irún, el Alarde de San Marcial, en conmemoración de aquel hecho histórico, y en el que la música desempeña un papel preponderante. Otro hecho histórico de gran relevancia fue la firma de la Paz de los Pirineos en la isla de los Faisanes en 1659, que ponía fin a la contienda entre España y Francia; dicha isla contemplará la celebración de conferencias políticas, bodas de Estado o intercambios de prisioneros entre España y Francia.

Ya en pleno siglo XIX, el 31 de agosto de 1813 tuvo lugar en Irún la Segunda batalla de San Marcial, en la que las tropas españolas junto con las aliadas anglo-portuguesas del Duque de Wellington derrotaron al ejército napoleónico, finalizando de esta manera la Guerra de la Independencia. Las tres Guerras Carlistas tuvieron asimismo su impronta en Irún, testigo de varias batallas y asedios a lo largo del siglo XIX que provocaron cuantiosos daños en los edificios de la población y numerosas bajas entre los habitantes de la ciudad. Por otra parte, y ya dentro del ámbito meramente económico, el traslado de las aduanas españolas a Irún en 1841 así como la llegada del ferrocarril en 1864 van a convertir a la ciudad guipuzcoana en uno de los centros de intercambio comercial y nudos de comunicación más importantes de España.

\section{ESTADO DE LA CUESTIÓN}

Irún experimentó una intensa vida musical, documentada desde el siglo XVII. Además de la práctica de la música religiosa, centrada en la capilla musical de la Iglesia Parroquial de Santa María del Juncal, principal centro eclesiástico de la ciudad, caben destacar las actividades de diversos grupos instrumentales que cultivan la música civil desde el siglo XVIII, y que constituirá el precedente de la Banda municipal de Irún, fundada en 1883.

La ausencia de estudios monográficos contribuyeron a un desconocimiento absoluto sobre la Capilla de música de la Iglesia Parroquial de Santa María del Juncal en Irún: así por ejemplo, no se conocía su organización, la composición de la Capilla, la estructura litúrgica, la función de la música en las celebraciones religiosas, la participación de dicha Capilla en la vida musical y cultural de la ciudad o la actividad de los Maestros-Organistas que estuvieron ejerciendo tal cargo a lo largo de los siglos. En su excelente libro Música vasca, la única y escueta referencia de José Antonio Arana a la música irunesa se centra en la figura de Vicente Quintana, que ejercía el cargo de Organista en $1746^{1}$. Por su parte, en el Diccionario de la Música Española e Hispanoamericana no se contenía un artículo dedicado a Irún y sólo se citaban en el

1 ARANA, 1987: 100. 
artículo "Guipúzcoa" ${ }^{2}$ los nombres de algunos de los organistas de Irún que habían desempeñado el cargo durante el siglo XVIII: Bartolomé Ferrer, Asencio Aurela, Vicente Quintana y Joaquín Martínez, si bien al organista del siglo XIX, Ramón Garmendia se consagraba un breve artículo, en el que se afirma que "durante 48 años fue organista en el órgano Cavaillé-Coll de la parroquia del Juncal (Irún)”3. Asimismo, el órgano Cavaillé Coll de Irún (1877) fue mencionado por Esteban Elizondo en su magnífica tesis doctoral al estudiar la figura de José Juan Santesteban, la cronología de los órganos Cavaillé-Coll en el País Vasco y Navarra, la restauración del órgano irunés en 1964, y por último, a la hora de explicar los factores que incidieron en la rápida expansión del órgano romántico francés en la zona vasco-navarra y especialmente en la provincia de Guipúzcoa ${ }^{4}$. Tendríamos que esperar al año 2008 para que la bibliografía musical de Irún se enriqueciera gracias a dos estudios: el primero sobre el órgano Cavaillé-Coll de la Iglesia de Santa María del Juncal y el segundo dedicado a la historia de las bandas de Irún ${ }^{5}$.

Por desgracia, apenas se ha conservado la obra musical de los Maestros-Organistas de la capilla de Santa María del Juncal en Irún. Sólo del citado maestro de la segunda mitad del siglo XIX y comienzos del XX, Ramón Garmendia, se conocen cinco obras catalogadas, que en la actualidad se conservan en el centro de documentación musical vasco Eresbil.

\section{LA IGLESIA PARROQUIAL DE SANTA MARÍA DEL JUNCAL}

\subsection{Introducción}

Las obras de edificación de la nueva Iglesia de Irún, considerada como una de las más esbeltas de toda la provincia de Guipúzcoa, se iniciaron el 4 de diciembre de 1508 cuando el Gobernador de Fuenterrabía, don Hurtado de Luna, colocó la primera piedra, prolongándose durante más de cien años ${ }^{6}$. Por entonces, la Parroquia de Santa María del Juncal dependía de Fuenterrabía y sólo conseguiría su independencia a mediados del siglo XVI, a pesar de lo cual siguió cediendo la mayor parte de sus diezmos a la parroquia matriz, tal como ha señalado Xavier Kerexeta ${ }^{7}$.

2 BAGÜÉS, ANSORENA, 2000, vol. 6: 76-85.

3 LEIÑENA, 1999, vol. 5: 518.

4 ELIZONDO, 2001: 42, 178-179, 398 y 490. Un resumen de esta tesis doctoral puede verse en ELIZONDO, 22-1 (Zaragoza, 2006): 121-130.

5 LANDART, 2008. SILGUERO, 2008.

6 Sobre la historia del proceso constructivo, consúltese BALENCIAGA, 10 (Irún, 1992): 229-260. Una detallada descripción de la estructura arquitectónica actual de Santa María del Juncal aparece en Declaración de Bien de Interés Cultural, 15 de Diciembre de 2004, Boletín Oficial del País Vasco, nº 2004238.

7 KEREXETA, Xabier, "Irún, ciudad fronteriza", http://www.alarde.org/a6/dimedeque/alardeas3.htm [consultado el 19 de Enero de 2010]. 


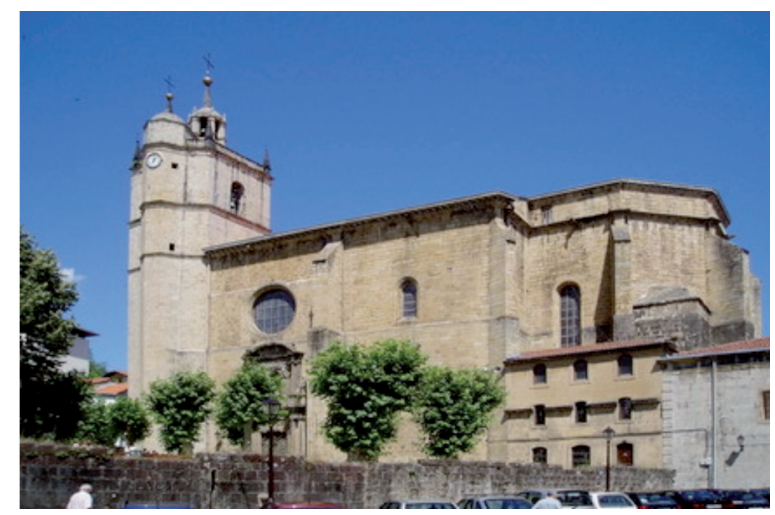

Figura 1. Iglesia Parroquial de Santa María del Juncal

Tuvo que transcurrir un siglo desde los comienzos de la construcción hasta que en 1606 se remató la obra principal. Es la prolongación en el tiempo de la construcción del templo irunés la que explica la superposición de estilos que puede observarse en el edificio: desde el gótico decadente de fines del XV, hasta el gótico vasco o renacentista vasco del XVI, en su segunda mitad y el barroco de la portada que es del siglo XVII: en este último siglo se añadieron el reloj, el órgano, la sacristía y un monumental retablo barroco, forrado de oro ya en el XVIII.

El patrono de la Iglesia Parroquial era el Ayuntamiento o Concejo, situado junto a la iglesia y denominado Serorategia: este sistema de patronato laico, según el cual se traspasaba gran parte del poder de la diócesis episcopal (como la elección de párrocos o recogida de diezmos), a los concejos o municipios, o bien en algunos casos a familias nobiliarias, era muy común en el País Vasco. Por su parte, las reuniones de vecinos tenían lugar en el cementerio (frente a la propia iglesia) o en alguna ocasión en la torre del campanario8.

\subsection{La Capilla de música de Santa María del Juncal antes del siglo XIX}

No se tiene constancia documental cuándo fue fundada la Capilla musical de la Iglesia Parroquial de Santa María del Juncal. Las primeras noticias se remontan al siglo XVII ya que el primer volumen de actas municipales conservadas en el Archivo Municipal de Irún datan del año 1645. Sin embargo es muy probable que ya existiera algún tipo de actividad musical desde el mismo momento de la consagración de la Iglesia.

Entre los músicos que ejercieron el cargo de organista antes del siglo XIX, está documentada la presencia en el siglo XVII de los organistas Juan de Berrotarán y Gregorio de Iriarte, mientras que los

8 Ibidem. 
organistas del XVIII son Bartolomé Ferrer, José Rojo, Asensio Aurela, José Uribarri, Vicente Quintana, Alejo de Sesma (interino), Joaquín Martínez y Miguel de Balzola, organista este último que sirve de puente entre el siglo XVIII y el XIX.

\subsection{La Capilla de música de Irún en el siglo XIX}

Gracias a la publicación del Reglamento de la Capilla Música de la Iglesia Parroquial Santa María del Juncal en la imprenta de Pío Baroja en 1860 conocemos las estructura y organización de dicha Capilla en el siglo XIX. El Reglamento consta de tres partes y un total de cuarenta artículos y además de la normativa que debe regir en la Capilla musical de Santa María del Juncal, también aborda las directrices por las que se debe guiar la "Música Marcial".

El Reglamento de 1860 establecía que la Capilla estaba formada por un Maestro-Organista, a cuyo cargo estaba la dirección de la mencionada Capilla y de todos sus efectivos, tanto vocales como instrumentales: entre los primeros se citan a un grupo de tiples (niños que ingresaban en el coro de la Capilla hasta que mudaban la voz) y un barítono ${ }^{10}$ : a primera vista puede parecer un coro reducido para hacer frente a las exigencias de la música coral religiosa pero el coro irunés de Santa María del Juncal podía ver ampliada su plantilla con el concurso de los beneficiados y capellanes de la propia Iglesia Parroquial y de los aficionados de la ciudad que pudieran colaborar tanto en el coro como en el grupo instrumental que acompañaba al mencionado coro ${ }^{11}$. Por lo que respecta a los efectivos instrumentales, además del órgano, sólo se nombra al bajón, antigua denominación que designaba al actual fagot. Sin embargo, un Reglamento de la Capilla citado con motivo del inicio del magisterio interino de Pedro Armero en $1874^{12}$ muestra un notable empobrecimiento por lo que se refiere a los componentes de la Capilla irunesa pues sólo cita expresamente al Maestro-Organista como miembro nato de la Capilla y no incluye ni los tiples ni al barítono, por lo que se debe recurrir a los "aficionados que buenamente gustaren desempeñar algún papel cantante".

El Reglamento de 1860 prescribe las funciones religiosas en las que debe intervenir la Capilla ${ }^{13}$, las cuales se clasifican en tres modalidades: funciones de primera clase, funciones de segunda clase y funciones especiales: entre estas últimas, se citan las de Santa Elena, en la Basílica, las de San Marcial y San Ramón, en la ermita así como aquellas funciones que determine el Ayuntamiento, para lo cual señalará "día, hora y clase de función"14.

9 Reglamento de la Capilla Música de la Iglesia Parroquial Santa María del Juncal y de la Música Marcial de la N. y L. M. B. y G. Villa de Irún, 1860.

10 Ibidem, 3.

11 Ibidem, 3.

12 Acta de 23 de Diciembre de 1874, Archivo Municipal de Irún, Irún (en adelante, AMI), vol. 96, fol. 9r.

13 Reglamento, 3ss.

14 Ibidem, 4. 


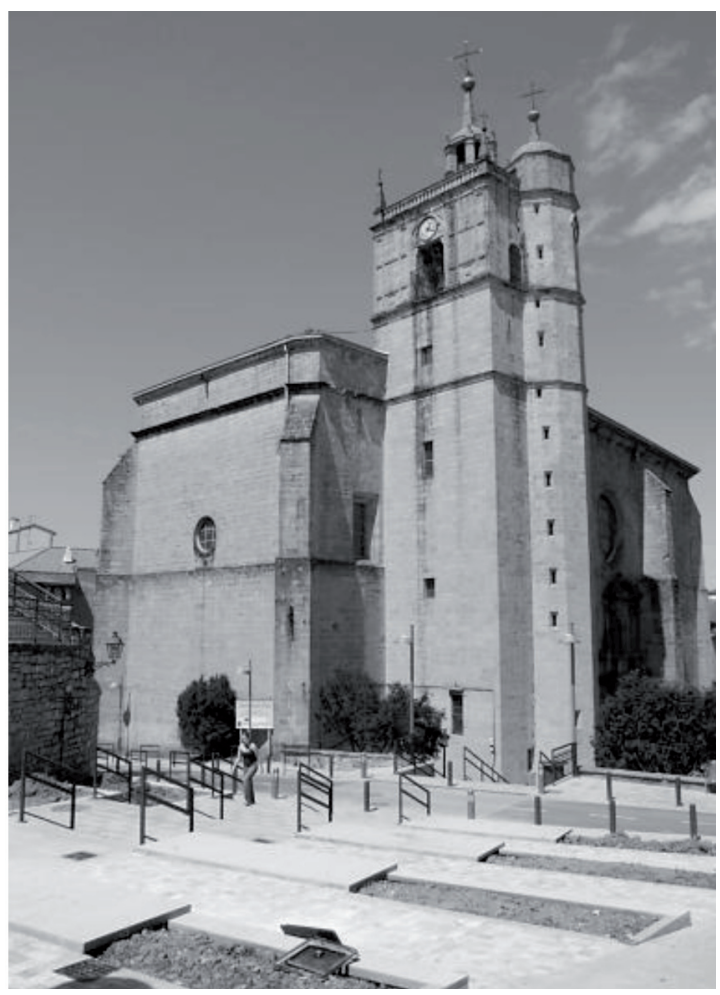

Figura 2. Torre-campanario de Santa María del Juncal

Tanto el grupo vocal como el bajón están obligados a la asistencia al coro de la Iglesia Parroquial todos los domingos y fiestas de precepto para cantar las misas mayores gregorianas ("en canto llano o figurado") acompañando al Cabildo de Santa María del Juncal ${ }^{15}$.

Entre las principales obligaciones que debe cumplir el Maestro de Capilla-Organista de Santa María del Juncal se cuentan las siguientes:

1) La dirección y gobierno de la Capilla musical, insistiendo en su responsabilidad para que las funciones eclesiásticas "se celebren con la solemnidad, majestad y decoro" que el día requiera, distribuyendo para el efecto la música necesaria en cada acto"16. 2) Composición de nuevas obras (que pasan a ser propiedad municipal) y búsqueda de variedad en la selección del repertorio "suprimiendo las composiciones que están ya demasiado repetidas, y siguiendo la misma regla con los villancicos de Navidad" 17 . 3) Enseñanza musical de cuatro tiples de la Capilla y de 16 niños de la ciudad. 4) Admisión y expulsión de los tiples de la Capilla. 5) Vigilancia en el cumplimiento y puntualidad de la asistencia de la Capilla a

15 Ibidem, 6

16 Ibidem, 6.

17 Ibidem, 6. 
las diferentes funciones obligatorias para que las "ejecuten con esmero la parte que les encarga y guarden el silencio, decoro y compostura que corresponde durante la celebración de los actos religiosos"18. 6) Selección de los Beneficiados y Capellanes de la Parroquia "que tengan buenas voces" y puedan intervenir en las funciones religiosas reforzando la Capilla habitual ${ }^{19}$.

7) Organización y dirección de una "academia" mensual con todos los componentes de la Capilla: se trataba de un concierto abierto a toda la ciudadanía. 8) Asistencia a todas las funciones religiosas antes citadas. 9) Mantenimiento y afinación del órgano de la Iglesia Parroquial. 10) En caso de ausencia por menos de dos semanas, deberá solicitar la correspondiente autorización al Alcalde "dejando un sustituto que haga las veces" (responsabilidad que puede asumir un miembro de la propia Capilla en casos de ausencia o de enfermedad del Maestro); para ausencias que exceden las dos semanas, se precisa la autorización del Ayuntamiento ${ }^{20}$.

En lo referente a las obligaciones que deben observar los componentes de la Capilla (cantores e instrumentistas) pueden destacarse las que a continuación siguen:

1) Puntual participación en todas las funciones obligatorias bajo la dirección del Maestro-Organista, a quien "respetarán y obedecerán" 21. 2) Asistencia a los ensayos y a los llamamientos "que el maestro juzgue necesarios en el sitio y hora que les designe"22. 3) En casos de duda en la interpretación de la normativa, prevalece la opinión del Maestro de Capilla-Organista, independientemente que se pueda recurrir posteriormente al Ayuntamiento en casos de gravedad. 4) Se puede obtener permisos del propio Maestro de Capillaorganista para ausencias de menos de ocho días pero si excede este periodo, se precisa la autorización del Alcalde. 5) En lo concerniente a las faltas de disciplina, aplicación en el estudio o dejación de funciones, serán "reprendidas la primera vez por el señor Alcalde"; si se cometiese una segunda falta, el municipio impondrá una multa; en caso de reincidencia, "se dará parte al Ayuntamiento para que le imponga mayor pena o le despida según fuese el caso" 23. 6) Una Comisión inspectora del Ayuntamiento será la encargada de hacer cumplir a todos los miembros de la Capilla musical la normativa emanada del vigente Reglamento.

El Reglamento de 1860 establece las posibles retribuciones a que puede aspirar el Maestro de Capilla-Organista ${ }^{24}:$ 1) Un sueldo fijo de 5500 reales anuales, del cual 4400 reales proceden de los fondos del culto y clero y los restantes 1100 del presupuesto destinado a la "Música Marcial". 2) Emolumentos no fijos obtenidos de su intervención al órgano en las celebraciones siguientes: 2.1 Bautizos: dos o cuatro reales, dependiendo si el padrino es irunés o forastero. 2.2 Bodas: cuatro o dieciséis reales, dependiendo si los novios son iruneses o forasteros. 2.3 Sesiones particulares, entierros y conmemoraciones: el precio que libremente fijen las partes.

18 Ibidem, 7.

19 Ibidem, 7.

20 Ibidem, 8.

21 Ibidem, 8 .

22 Ibidem, 8.

23 Ibidem, 9.

24 Ibidem, 11-12. 


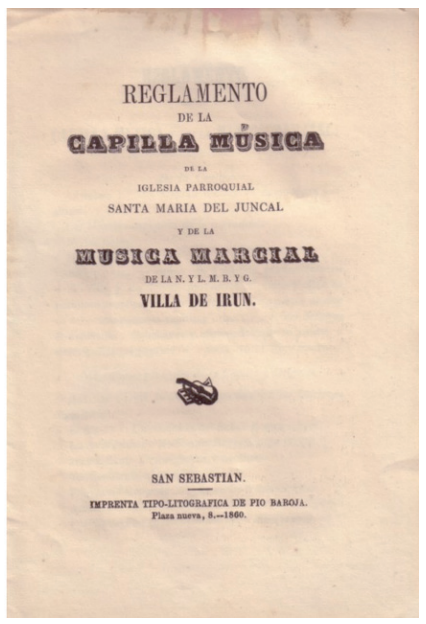

Figura 3. Portada del Reglamento (1860)

\section{MAESTROS DE CAPILLA-ORGANISTAS DE IRÚN EN EL SIGLO XIX}

\subsection{Joaquín Tadeo Murguía, Organista interino}

En 1780 había quedado vacante el magisterio irunés por fallecimiento del Organista y Maestro de Capilla titular, Joaquín Martínez, suceso acaecido el día 13 de enero de aquel mismo año ${ }^{25}$. El músico irunés y sacristán de la Iglesia de Santa María del Juncal, Joaquín Tadeo de Murguía (1759-1836), fue el encargado de desempeñar interinamente la organistía durante la enfermedad de Joaquín Martínez y con motivo del fallecimiento de éste, remite un memorial al Ayuntamiento de Irún en el que afirma que

“con relación a lo referido de la instrucción que ha adquirido en la facultad de Organista y de haberse servido durante la enfermedad de dicho Martínez desempeñando, según es notorio, y por la circunstancia del mérito de estarse empleado en la misma Iglesia, a imitación de su padre y demás ascendientes en calidad de sacristán, suplica a la universidad le confiera el empleo de Organista..."26.

El Consistorio acepta que Murguía asuma provisionalmente la plaza de Organista pero deja claro que la plaza ha de cubrirse por oposición: “....se proceda a la provisión de la plaza vacante de dicho órgano por medio de una oposición rigurosa, abriéndose y llamando a cualquiera profesores para que se le dé y confiera al más benemérito, según se ha hecho en otras semejantes ocasiones de oposición"27.

25 Acta de 16 de Enero de 1780, AMI, vol. 31, fol. 9r.

26 Ibidem, fol. $9 \mathrm{v}$.

27 Ibidem, fol. 10r. 


\subsection{Miguel de Balzola}

Al cabo de cuatro meses tuvieron lugar las oposiciones a la plaza de Organista de Santa María del Juncal, resultando vencedor de las mismas el músico originario de Guernica, Miguel de Balzola:

"Y en consecuencia de todo, y porque el ilustre examinador que ha asistido en la oposición hecha, ha dado en el primer lugar el grado primero a don Miguel de Balzola, natural de la villa de Guernica, en el Señorío de Vizcaya, desde luego eligen y nombran a dicho Balzola para todos los días de su vida por Organista de la referida Iglesia, para que lo sea y sirva con la renta anual, calidades y condiciones que constan de las citadas diligencias, otorgándosele la correspondiente escritura de conducción vitalicia la tarde de este día”28.

Miguel de Balzola Garamendi Emparanza y Arribalzagogesacoa ${ }^{29}$ nació en Guernica en fecha desconocida. Su padre, Miguel de Balzola Emparanza, era natural de la villa de Vergara, donde nació en torno a 1730, y fue tío de Juan Crisóstomo Arriaga.

Al mismo tiempo que Miguel de Balzola tomaba posesión de la plaza de Organista de Irún en 1780, Joaquín Tadeo de Murguía renunciaba a sus puestos como Organista interino y Sacristán, sin que aclaren nada las actas municipales sobre las causas de su dimisión. Nos preguntamos si Murguía se presentó a las oposiciones: lo más lógico es responder afirmativamente a esta cuestión (se habla de la elección de Balzola "en el primer lugar") y al no obtener la plaza, posiblemente Murguía se sintió defraudado con su ciudad natal y prefirió abandonar Irún:

“...que habiéndosele conferido por la misma universidad dicho empleo, lo ha servido por espacio de algunos años y en la actualidad, se ve en la precisión de ausentarse, y por consiguiente en la de no poder servir en adelante, y suplica se le admita la dejación que hace de dicha plaza y provea la misma en el sujeto que reconociese por más capaz, en cuya vista se acordó admitir y se admitió la dejación que se hace de dicho empleo de sacristán, declarando desde ahora por vacante a la disposición de la universidad para su provisión como Patrona de la referida Iglesia" ${ }^{30}$.

Lo cierto es que el músico irunés Joaquín Tadeo de Murguía protagonizó posteriormente una exitosa trayectoria, desempeñando la prestigiosa plaza de Organista de la Catedral de Málaga ${ }^{31}$. Para ocupar su puesto como Sacristán en Irún, Antonio de Guevara presentó una solicitud al Ayuntamiento pero su propuesta no fue aceptada ${ }^{32}$.

En febrero de 1796 Balzola se encontraba en Madrid, sin que las actas municipales citen las razones de su ausencia, la cual se alargó de tal manera (desde 1794 nos consta el abandono de sus responsabilida-

28 Acta de 16 de Abril de 1780, AMI, vol. 31, fol. 82r.

29 Genealogía 2765, Archivo Histórico Foral de Bizkaia, Registro 209.

30 Acta de 16 de Abril de 1780, AMI, vol. 31, fol. 82v-83r.

31 Sobre Joaquín Tadeo de Murguía véanse MARTÍN QUIÑONES, 1987. CAPDEPÓN, 48 (Madrid, 2008): 131-148.

32 Acta de 16 de Abril de 1780, AMI, vol. 31, fol. 83r. 
des en Irún) que el Ayuntamiento apremió por escrito a su Organista para que regresara a Irún en el plazo de un mes y retomara sus funciones, amenazándole incluso con declarar vacante la organistía:

"Confiérese sobre la morosidad del Organista para su regreso. Por cuanto se extraña mucho la morosidad que se reconoce en don Miguel Balzola, Organista de dicha Iglesia Parroquial de esta universidad, sin que trate de su regreso al cumplimiento de su obligación y no es posible se disimule, acordó este congreso se le escriba a la villa de Madrid, donde se halla, dándole a entender para que en el término de un mes desde esta fecha, se presente o haga desistimiento, en la inteligencia de que de no hacer así, ya luego pasado dicho término, dará la universidad por vacante la plaza que ocupa dicho Balzola y procederá a su provisión" 33 .

Al cabo de varios días, Balzola respondió a las autoridades municipales de Irún desde Madrid, pretextando el mal estado del tiempo como explicación para la tardanza de su regreso, ante lo cual el Ayuntamiento acepta prorrogar el plazo dado para el retorno a Irún:

"Habiéndose también leído en este acto la carta de don Miguel de Balzola, Organista de la Iglesia Parroquial Santa María del Juncal de esta universidad, su fecha en Madrid tres del mes corriente, que es respuesta a la que ella le escribió en veinticinco de febrero último en razón de su morosidad, prefijándole término para su regreso al desempeño de su obligación, con la prevención de que no verificándolo se daría por vacante plaza y procedería la universidad a su provisión, con esta vista y respecto de que entre los fundamentos que pretexta para diferir su venida pidiendo prorrogación de término, el único atendible es la causa del rigor del tiempo que en realidad se ha experimentado. Acordó este congreso que por lo mismo corra el término que se le concedió hasta el día quince del mes próximo venidero de abril, y que cumplido, y no verificándose para aquel día la llegada de dicho Balzola, se guarde, cumpla y ejecute el decreto, hecho en ayuntamiento del citado día veinticinco de febrero, según su ser y tenor, llevándose a su debido efecto en todo y por todo" 34 .

Las relaciones de Balzola con sus superiores se agravaron a causa de su ausencia hasta tal punto que el organista guerniqués acudió al Supremo Consejo de Castilla con el fin de buscar amparo en dicho organismo central para que el Ayuntamiento "no le moleste ni precise a ello por término de cuatro meses" 35 . Ante la actitud de Balzola, a quien se recrimina el camino elegido, el Ayuntamiento decide recurrir asimismo al Supremo Consejo de Castilla (delegando esta vía en un vecino de Madrid), y en último caso, declarar vacante la plaza de Organista si Balzola no regresara a Irún antes del plazo impuesto del quince de abril de $1796^{36}$. Transcurrido el plazo, en junio seguía Balzola ausente de sus funciones en la Iglesia de Santa María del Juncal y durante este tiempo desempeñó la organistía de manera provisional Juan José de Boneta, iniciativa adoptada por el propio Balzola, con la que el Ayuntamiento no está de acuerdo pues el citado Boneta la "verifica desconociendo su obligación y faltando a ella, valiéndose de

33 Acta de 25 de Febrero de 1796, AMI, vol. 41, fol. 50v.

34 Acta de 21 de Marzo de 1796, AMI, vol. 41, fol. 68v-69r.

35 Acta de 27 de Marzo de 1796, AMI, vol. 41, fol. 77v.

36 Acta de 27 de Marzo de 1796, AMI, vol. 41, fol. 77r-v 
medios impropios" ${ }^{\prime 37}$. Afirma el Alcalde que el ocho de junio se presentó Boneta en su casa por la noche para comunicarle que al día siguiente abandonaría sus funciones como Organista en Irún para tomar posesión en la villa riojana de Uzquirrita, proponiéndole como sustituto a un músico ciego, alternativa que no convence en absoluto al Alcalde irunés, llegándose a la conclusión de que "se halla desairada de nuevo la universidad de parte de don Miguel de Balzola, acreditándose más el abandono con que tiene su obligación y los efectos impropios con que se maneja". Ante tal situación se plantea elegir un nuevo Organista en la Iglesia Parroquial de Santa María del Juncal. ${ }^{38}$

El 27 de junio de 1796, y después de varios meses de ausencia, Miguel de Balzola se encuentra de regreso en Irún, ocasión que es aprovechada por el Ayuntamiento para recordar a su Organista que estuvo a punto de perder su plaza y que en el futuro debe respetar las obligaciones inherentes al cargo:

“...podía y debía la universidad declarar por vacante la plaza que se le estaba conferida, y no lo ha hecho por ciertas consideraciones, sin embargo de verse penetrada con el dolor de tantos y tan impropios hechos, y los medios de que ha pretendido aprovecharse dicho Balzola, haciéndole saber para en adelante, por si absolutamente ha olvidado las circunstancias de su conducción, leyéndole la escritura otorgada en dieciséis de abril de mil setecientos y ochenta..."39.

Además, se acuerda no abonar el salario de Balzola desde el 15 de abril hasta su regreso a finales de junio. Gracias a este documento, sabemos que Balzola había estado ausente de Irún desde dos años antes $^{40}$.

Parece que los siguientes años del magisterio de Balzola fueron relativamente tranquilos pues las actas no lo mencionan hasta 1803 , cuando solicita al ayuntamiento la reparación del órgano, debido a su estado de deterioro. El memorial de Balzola dice así:

"Don Miguel de Balzola, Organista de la Iglesia Parroquial de ella, con el respeto debido, expone a V. S., que mediante hallarse bastante deteriorado el órgano que está a su cuidado por falta de un apeo general y composición de fuelles, y de no ocurrir a tiempo a ella, podrían resultar mayores gastos que en de concepto según los informes que ha adquirido, ascenderán a mil reales poco más o menos, pone en consideración de V. S. para que providencie lo que tuviere por más conveniente. Irún, 8 de enero de 1803. Miguel de Balzola" ${ }^{41}$.

El Ayuntamiento aceptó las razones expuestas en el memorial de su Organista y comisionó a dos concejales para que verificaran la reparación del órgano de Santa María del Juncal ${ }^{42}$ y se encarga al maestro organero Diego de Amezúa esta labor ${ }^{43}$. Siete años después, en 1810 vuelven a surgir problemas con

37 Acta de 12 de Junio de 1796, AMI, vol. 41, fol. 122v.

38 Acta de 12 de Junio de 1796, AMI, vol. 41, fol. 122v-123r.

39 Acta de 28 de Junio de 1796, AMI, vol. 41, fol. 137r.

40 Acta de 28 de Junio de 1796, AMI, vol. 41, fol. 137v.

41 Acta de 8 de Enero de 1803, AMI, vol. 46, fol. 17r.

42 Acta de 9 de Enero de 1803, AMI, vol. 46, fol. 14v.

43 Acta de 29 de Junio de 1803, AMI, vol. 46, fol. 210 r. 
el órgano: en esta ocasión son los fuelles del cilindro los que precisan renovarse y nuevamente es Diego de Amezúa el encargado de asumir esta tarea ${ }^{44}$. Relacionado con el órgano durante la etapa de Balzola, sabemos que al mes siguiente (abril de 1810) fue contratado Bernardo de Sistiaga para asumir la plaza de manchador. Asociada al organista aparece la figura del manchador, que era una especie de entonador o palanquero: su función consistía en mover los fuelles del órgano pues el sonido del órgano dependía del viento al ser activados dichos fuelles manualmente ${ }^{45}$.

A pesar de la querella causada a finales del siglo XVIII por su ausencia, como ya hemos visto, el prestigio de Miguel de Balzola fue en aumento, como lo demuestra el hecho de debatir el nombramiento del Organista de Irún como consejero municipal, nombramiento que no puede efectuarse por la falta de refrendo por parte de la Intendencia provincial ${ }^{46}$. Sin embargo, un nuevo conflicto estalla entre el Ayuntamiento y su Organista, relativo al asunto de la casa seroral y huerta que disfrutaba Balzola, acordándose introducir una rebaja de 450 reales de vellón en su salario como renta de las dos propiedades ${ }^{47}$. Al año siguiente, Balzola solicita que se le restituya la casa seroral y su huerta así como un terreno de labor en Arrainputzu, acordando el Ayuntamiento irunés concederle una compensación económica al no poder restituirle las propiedades ${ }^{48}$.

Después de más de 37 años de servicio como Organista de la Iglesia de Santa María del Juncal de Irún, Miguel de Balzola dimite de su puesto el 4 de junio de 1817 debido a sus continuos problemas de salud, tal como él mismo manifiesta en un memorial dirigido al Ayuntamiento irunés, solicitando al mismo tiempo ayuda económica para hacer frente a los gastos que acarrea su enfermedad:

"Don Miguel de Balzola, Organista de la Iglesia Parroquial de la misma villa, con el debido respeto, hace presente a V. S. la imposibilidad que me hallo para desempeñar dicho empleo de Organista a causa de mi habitual enfermedad, por la cual me veo precisado hacer desistimiento de él, y en atención haberle ejercido por espacio de treinta años a satisfacción de todos, a V. S. suplico se digne mandar señalarme un diario suficiente para los días de mi vida a fin de que con él pueda soportar los crecidos gastos que acarrea dicha enfermedad; y en ello recibiré merced. Irún, 4 de junio de 1817. Miguel de Balzola”49.

El Ayuntamiento aborda la solicitud de Balzola el nueve de junio de 1817, refiriéndose a la enfermedad que le ha llevado a la dimisión de su puesto: “...de resulta de un insulto paralítico y le tiene después acá impedido de todos sus nervios como también los continuos ataques que con frecuencia le sobrevienen..." ${ }^{50}$. El Consistorio acepta la petición de su Organista, consignándole la mitad de su salario (200 ducados de vellón), reservando los restantes 200 para la provisión del nuevo organista, a los que

44 Acta de 8 de Marzo de 1810, AMI, vol. 53, fol. 90r-v.

45 Acta de 8 de Abril de 1810, AMI, vol. 53, fol. 114v-115r.

46 Acta de 16 de Enero de 1813, AMI, vol. 56, fol. 18r-v.

47 Acta de 25 de Marzo de 1813, AMI, vol. 56, fol. 66r-67r.

48 Acta de 28 de Diciembre de 1814, AMI, vol. 57, fol. 264v-265v.

49 Acta de 4 de Junio de 1817, AMI, vol. 60, fol. 243r.

50 Acta de 9 de Junio de 1817, AMI, vol. 60, fol. 241v. 
habrá que añadirse 100 ducados procedentes de la fábrica de la iglesia de Santa María del Juncal ${ }^{51}$. Al poco tiempo se recibe contestación por parte del Provisor y Vicario General de este Obispado aceptando el aumento de cien ducados acordado por el Ayuntamiento pero limitándolo a los años que le queden de vida a Balzola, planteamiento que causa el rechazo de la corporación municipal argumentando el encarecimiento del coste de la vida:

“...que el espíritu y mente de esta villa de Irún, cuando celebró su acuerdo del citado día cuatro de junio último sobre la nueva dotación del Organista efectivo, que en lo sucesivo ha de servir en esta dicha Iglesia Parroquial, es y era el de que el aumento que se hizo de los especificados cien ducados de vellón a los cuatrocientos que el año de mil setecientos ochenta se consignaren a don Miguel de Balzola fuese perpetuo, como lo desea esta villa de Irún, teniendo presente por ello y trayendo a consideración la suma carestía y alteración de precios que desde aquella época al presente han tenido y se experimenta tanto en los comestibles como en todo lo demás tocante a la decencia, porte y lucimiento con que por su carácter le es indispensable presentarse en el público" 52 .

Dos años después de la jubilación de Balzola, éste reclama el devengo de su salario, situación en la que asimismo se encuentra el médico, el cirujano y el maestro de la villa ${ }^{53}$. Conociendo el Ayuntamiento esta circunstancia en el retraso de los citados salarios, acuerda al mes siguiente que éstos se satisfagan de las partidas destinadas al sostenimiento de las tropas acantonadas en Irún ${ }^{54}$. A pesar del acuerdo adoptado en marzo de 1819, cinco meses después los salarios pendientes aún no habían sido devengados, lo que provoca un nuevo memorial de los afectados, en el que exponen que su situación es "deplorable" y que "están llenos de deudas y no tienen recurso alguno para vivir": en esta ocasión el Consistorio les promete destinar parte de los réditos de unos derechos de la villa a la satisfacción de las deudas contraídas con el Médico, Cirujano, Maestro y Organista jubilado de la villa ${ }^{55}$.

Miguel de Balzola falleció, según el auto de defunción conservado en el Archivo Histórico Diocesano de San Sebastián, el 23 de abril de $1823^{56}$.

\subsection{Juan Antonio Prol, Maestro de capilla-Organista interino}

Entre 1817, año de la jubilación de Balzola, y 1822, Juan Antonio Prol entró al servicio de Santa María del Juncal en calidad de Organista provisional. Las actas municipales, sin embargo, no mencionan este hecho ya que la primera mención a Prol se remonta al 22 de febrero 1822 cuando se dirige al Ayun-

51 Acta de 9 de Junio de 1817, AMI, vol. 60, fol. 242r.

52 Acta de 13 de Agosto de 1817, AMI, vol. 60, fol. 313v.

53 Acta de 10 de Febrero de 1819, AMI, vol. 62, fol. 75v.

54 Acta de 14 de Marzo de 1819, AMI, vol. 62, fol. 94v.

55 Acta de 10 de Agosto de 1819, AMI, vol. 62, fol. 323r-v. $142 \mathrm{v}$.

56 Defunciones: 1803-1830, Archivo Histórico Diocesano de San Sebastián, Fondo Santa María del Juncal en Irún, fol. 
tamiento como "sustituto de don Miguel Balzola" solicitando que se jubile definitivamente, aunque el Ayuntamiento no adopta ninguna decisión al respecto por el momento:

"Igualmente se leyó un memorial de don Juan Antonio Prol, Organista y sustituto de don Miguel Balzola, suplicando al Ayuntamiento la jubilación del propietario dicho Balzola pues que éste se halla enteramente inhábil para poder ejercer la obligación contraída con la villa. En consecuencia y de no poder dar solución a dicho memorial por carecer el Ayuntamiento de datos sobre el particular, quedó esta solicitud para otro ayuntamiento comisionando a don Francisco José de Olazábal para hablar con el ilustre Cabildo eclesiástico con este motivo; de que doy fe, yo el secretario" ${ }^{57}$.

\subsection{Agustín Cayetano Echaide}

Dado que Miguel de Balzola había fallecido en abril de 1823, en agosto del mismo año, el Consistorio irunés decidió sacar a oposición la plaza de Maestro de capilla-Organista de la Iglesia de Santa María del Juncal publicando los preceptivos edictos en la provincia y zonas limítrofes -como, por otra parte, era usual en la época- , no sin advertir a los candidatos que debían haber observado una conducta política "irreprensible", demostrable mediante la oportuna documentación, entendiendo por tal conducta la no adscripción a los ideales liberales y constitucionalistas:

"Hallándose como se halla vacante la plaza de Organista de la Iglesia Parroquial por fallecimiento del anterior poseedor, don Miguel de Balzola, y debiendo proceder a su nueva presentación y nombramiento a oposición un Maestro Organista o sinodal, según ordenanza municipal, previa anunciación por edictos en los pueblos de esta provincia e inmediatos, se acordó que desde luego se ocupe en las diligencias que encarga la misma ordenanza y comisionó el ayuntamiento al señor Alcalde Aguinaga para que valiéndose del señor doctor don Juan Antonio de Oronoz, Rector Cancelario y Catedrático en la Universidad de Reales Estudios de Oñate, proporcione un Maestro Organista, sea en dicho pueblo o en los inmediatos que haga de sinodal al tiempo de la oposición y que, evacuada, se anuncie ésta y la vacante por medio de edictos que se fijaran en dichos pueblos; advirtiendo a los pretendientes que no se les admitirá a la oposición si no viene revestido cada uno de ellos de documento por el que se acredite con arreglo al artículo quinto de la real orden de veintisiete de junio último haber observado una conducta irreprensible en lo político y en el orden social durante el pretendido sistema constitucional ya extinguido" 58 .

Tres días después el Consistorio vuelve a tratar la cuestión de las oposiciones a la organistía decidiendo, entre otros aspectos, la elección de un "maestro examinador" así como la promulgación de edictos; de nuevo se vuelve a insistir en la necesidad de no haber participado en los disturbios políticos que por entonces acaecieron en España con motivo de la derogación del sistema constitucional y el consiguiente comienzo de la denominada "Década ominosa" durante el reinado de Fernando VII:

57 Acta de 13 de Febrero de 1822, AMI, vol. 66, fol. 83r-v.

58 Acta de 7 de Agosto de 1823, AMI, vol. 68, fol. 457v-458r. 
"Así bien expusieron los señores del Gobierno que en el ayuntamiento ordinario de siete de este mes se trató del nombramiento del nuevo Organista de la Iglesia Parroquial de esta villa, vacante por fallecimiento de don Miguel de Balzola, anterior poseedor y que el Ayuntamiento comisionó al señor Alcalde Aguinaga para buscar un maestro examinador que presenciase la oposición a que debía ir la elección de dicho nuevo Organista con arreglo a ordenanza. La Junta, aprobando lo hecho por el Ayuntamiento ordinario y convencida de la necesidad del nombramiento que exponen los señores capitulares, acordó comisionar y comisionó a los señores Alcalde Aguinaga y a José Joaquín de Escorza para que, previo conocimiento de la dotación que compone la plaza de Organista de esta villa y aclarándola como corresponde, se ocupen de las diligencias de anunciar por edictos para la concurrencia de los pretendientes y que la presentación y nombramiento se haga a oposición con arreglo a ordenanza, interviniendo como tales nombrados en el expediente que se formara, en la inteligencia que en los edictos hagan entender a los opositores que no se admitirá ninguno de ellos que no venga revestido de un documento por el que se acredite con arreglo al artículo quinto de la real orden de veintisiete de junio último, no haber tenido parte en los desórdenes de la época pasada" ${ }^{59}$.

Tres días después el Ayuntamiento decreta que el Cabildo de Santa María del Juncal se hará cargo de la tercera parte de los gastos que ocasionen las oposiciones a la organistía de la citada iglesia, siendo esta la costumbre practicada desde tiempo atrás ${ }^{60}$. El Cabildo respondió en sentido positivo a la solicitud del Consistorio de Irún para sufragar la tercera parte de los gastos ${ }^{61}$.

Un informe incompleto (no indica el día de la convocatoria ni el sueldo exacto de la plaza) y no incluido en las actas municipales, esclarece algunos aspectos de la convocatoria y los derechos que llevaba anexa la plaza: así por ejemplo se aclara que el salario, equivalente al de un beneficiado de la iglesia, incluye los gastos derivados de la vivienda o de la asistencia médica para toda la familia del Organista. Además se exige a los candidatos el dominio del canto gregoriano ("canto llano") y de la técnica compositiva; de nuevo se alude a la fidelidad política al sistema absolutista que el nuevo Organista elegido debe demostrar:

"Se hace saber que la oposición al órgano de la Iglesia Parroquial Santa María del Juncal de esta N. y L. muy benemérita villa de Irún, en la M. N. y M. L. provincia de Guipúzcoa, será el día [en blanco] de noviembre del presente año de 1823. Este órgano tiene de renta en cada año [en blanco] ducados de vellón (que sirven para la renta de la casa de la habitación del Organista), todos pagaderos en dinero efectivo fuera de réspices que son iguales a los de los señores beneficiados y otras utilidades; y además tiene médico, cirujano y botica de balde para las dolencias y enfermedades suyas y de toda su familia. Los que quieran entrar a dicha oposición, que deberán saber canto llano y de composición, podrán concurrir el día asignado, sólo se les donará el gasto que hicieren en Irún en los días que durare; y consiguiente a lo que tiene decretado la misma villa, el que fuere aprobado deberá ser adicto al Rey y de ningún modo el que haya rozado en la más mínima cosa en el pretendido sistema constitucional para lo que, sin perjuicio de los informes secretos que tomará dicha villa o sus comisionados, tendrá que acreditarlo en forma debida la justificación de su conducta política, antes que tome la posesión de dicho órgano. Cuyo edicto proyectamos hacer fijar en los parajes convenientes. Y lo firmamos en Irún a [en blanco]”ø2.

59 Acta de 10 de Agosto de 1823, AMI, vol. 68, fol. 509r-v.

60 Acta de 10 de Octubre de 1823, AMI, vol. 68, fol. 672r.

61 Acta de 22 de Octubre de 1823, AMI, vol. 68, fol. 688v.

62 Documentación referente al nombramiento y servicios de organista, AMI, Sección E, Negociado 4, Serie II, Libro $n^{\circ} 4$, Expediente $n^{\circ} 3$, Asunto: Relaciones con las autoridades eclesiásticas, 1773-1853. 
A las oposiciones, celebradas en un día indeterminado de noviembre de 1823, se presentaron la nada despreciable cifra de ocho candidatos, según se desprende del acta municipal del 28 de noviembre de 1823. El anónimo "maestro examinador" que presidió las oposiciones eligió en primer lugar a Agustín Cayetano Echaide Mugerza, el cual había nacido en la localidad guipuzcoana de Cestona el siete de agosto de $1801^{63}$ y antes de asumir su nuevo cargo en Irún desempañaba la función de Organista en la Iglesia Parroquial de su ciudad natal.

Los dos comisionados por el Ayuntamiento para verificar el proceso de elección de nuevo Organista (el Alcalde Aguinaga y el Concejal Escorza) son los encargados de recabar la pertinente información sobre la conducta política de Echaide ${ }^{64}$. Éste se vio en la necesidad de demostrar la probidad de su conducta moral y política mediante pruebas documentales procedentes de la toma de declaración de cuatro testigos de su pueblo natal de Cestona, elegidos por el propio Echaide, ante el Teniente de Alcalde de Cestona, Ramón de Lizaso. Así por ejemplo, el primer testigo fue Alejo de Azpeitia, Vicario de la Iglesia Parroquial de Cestona, quien atestigua que Echaide "ha residido constantemente en esta villa en todo el tiempo que ha regido el pretendido gobierno constitucional, observando la mejor conducta política, sin que haya tomado la menor parte por ella", demostrando en todo momento su adhesión a la causa realista, razón por la que fue nombrado Capitán de la Milicia Sedentaria de Cestona, "cuyo cargo está desempeñando a toda satisfacción de ella”. El segundo testigo aportado por Echaide fue otro presbítero de la Iglesia de Cestona (donde, recordemos, trabajaba como Organista), llamado Gracián de Celaya, quien vuelve a reafirmar la fidelidad política de Organista a la causa absolutista: “....sin que haya sido voluntario ni hecho armas contra los realistas, sino al contrario ha sido uno de tales y de los más decididos por la causa del Rey Nuestro Señor". Por su parte, el tercer testigo, el vecino Manuel de Embil, afirma que Echaide ha observado "la mejor conducta política, manifestando su oposición a él, y la mas decidida adhesión a la causa del Rey nuestro señor (que Dios guarde)", afirmación asimismo compartida por el cuarto testigo, Tomás de Querejeta, Diputado del común de Cestona, para el que Echaide ha demostrado "la mejor conducta política, sin haberse mezclado en lo más mínimo de cosas de aquella época, antes bien muy separado de ellas, ha conservado la más decidida adhesión a la causa del Rey Nuestro Señor"65.

Una vez superada la prueba de la fidelidad política del nuevo Organista al régimen político entonces imperante por "no haber rozado en los desórdenes de la época pasada", el 28 de diciembre de 1823 se otorga la posesión definitiva a Echaide ${ }^{66}$. No volvemos a tener noticia de ninguna actividad musical durante el magisterio de Echaide hasta mayo de 1826, cuando el nuevo manchador del órgano, Juan José de Mocorrea, solicita al Consistorio irunés una gratificación por su trabajo ${ }^{67}$.

63 Bautismos: 1767-1808, Archivo Histórico Diocesano de San Sebastián, Fondo Natividad de Nuestra Señora en Cestona, fol. 118r. Según esta información sus padres eran Pedro Echaide Guesalaga y María Ignacia Mugerza Egaña.

64 Acta de 28 de Noviembre de 1823, AMI, vol. 68, fol. 754r-755r.

65 Información de don Agustín Cayetano de Echaide sobre su conducta política (1823), AMI, Sección E, Negociado 4, Serie II, Libro $n^{\circ} 4$, Expediente $n^{\circ}$ 3, Asunto: Relaciones con las autoridades eclesiásticas, 1773-1853.

66 Acta de 28 de Diciembre de 1823, AMI, vol. 68, fol. 837v.

67 Acta de 24 de Mayo de 1826, AMI, vol. 71, fol. 239v-240r. 
Una de las obligaciones de los Maestros de Capilla y Organistas en las instituciones eclesiásticas españolas consistía en la enseñanza musical, que en ocasiones supone más bien una carga; Echaide solicita que dicha obligación se limite a dos tiples:

"Se leyó el memorial de don Agustín Cayetano de Echaide, Organista de [la] Parroquia de esta villa de primero del corriente, en que otras cosas, espera que una de sus obligaciones es el de enseñar de balde la música a los hijos del pueblo que quieran aprender y desea él que la obligación arriba citada reduzca esta villa al de dos tiples eligiendo en la escuela de las mejores voces mejores voces que haya, en lo que se conseguirá que el coro esté siempre ordenado con dos jóvenes útiles para solemnizar las funciones de la Iglesia y suplica a la misma villa tenga a bien acceder a esta solicitud. En cuya vista acordó este ayuntamiento general conceder, como le concede, lo que pide, señalando, como señala, a cada uno de los dos tiples ochenta reales [de] vellón, es decir, ciento sesenta a ambos, pagaderos de los fondos de la fábrica" ${ }^{98}$.

Durante el magisterio de Echaide las relaciones entre las autoridades municipales y el Cabildo de Santa María del Juncal no siempre están exentas de tensiones. El propio Echaide interviene como intermediario para transmitir al Ayuntamiento que el Rector de la citada Iglesia Parroquial ha prohibido que la "banda músicos aficionados" participen en las procesiones de la Semana Santa de 1830. El Alcalde irunés manifiesta no sólo su desacuerdo sino también que esta medida haya sido tomada sin su conocimiento ${ }^{69}$.

Las actividades de Echaide no se limitaron durante su mandato a las habituales de un maestro de capilla de la época (interpretación al órgano, dirección de la Capilla, composición de nuevas obras para el culto, enseñanza musical, etc.) sino que, a comienzos de 1831, también fue encargado por el Ayuntamiento del cuidado del reloj por poseer "alguna inteligencia en la materia" ${ }^{70}$. Por otra parte, el mantenimiento y reparación del órgano de la Iglesia del Juncal constituye uno de los quebraderos de cabeza para todos los Maestros de Capilla-organistas que han ejercido el cargo en dicha institución eclesiástica a lo largo de su historia. Es asimismo el caso del maestro Echaide, quien solicita en esta ocasión la reparación de los fuelles antes de que queden completamente inutilizados:

"Enseguida se ha hecho lectura del memorial presentado a nombre de don Agustín Cayetano de Echaide, Organista de la Iglesia Parroquial de esta villa, por el que manifiesta que los fuelles del órgano de dicha Iglesia se hallan inutilizados casi en todo para el servicio a que son destinados y suplica se tome en consideración su estado antes que se inutilicen para repararlos. Y enterado el Ayuntamiento de la exposición de Echaide, acordó se ponga en conocimiento del Mayordormo de la fábrica, don Javier de Gurruchaga, cuanto expone el Organista para que de acuerdo con el mismo hagan que a la mayor brevedad posible se reparen los fuelles a fin de evitar gastos de mayor cuantía que podrían ocasionarse a falta de dicha reparación, valiéndose al efecto de artífice inteligente y conviniendo con él, en el tanto a cuanto, pero curando siempre la mayor economía en beneficio de los fondos de la Iglesia y que se haga saber por el secretario a dicho Organista esta determinación"71.

68 Acta de 3 de Febrero de 1827, AMI, vol. 72, fol. 48r-v.

69 Acta de 4 de Abril de 1830, AMI, vol. 76, fol. 98v.

70 Acta de 3 de Enero de 1831, AMI, vol. 77, fol. 4v-5r.

71 Acta de 25 de Noviembre de 1832, AMI, vol. 78, fol. 328 r. 
No se han conservado más noticias de Echaide en las actas municipales entre 1833 y 1837, año en que Echaide, acérrimo partidario del bando carlista, se ve en la obligación de abandonar el puesto de Organista por haber sido hecho prisionero en el transcurso del asalto de Irún por tropas inglesas en mayo de 1837 y trasladado a la cárcel de La Coruña, tal como se desprende de la reclamación que efectúe años después solicitando la readmisión como Organista de Santa María del Juncal (Acta municipal de 11-41859).

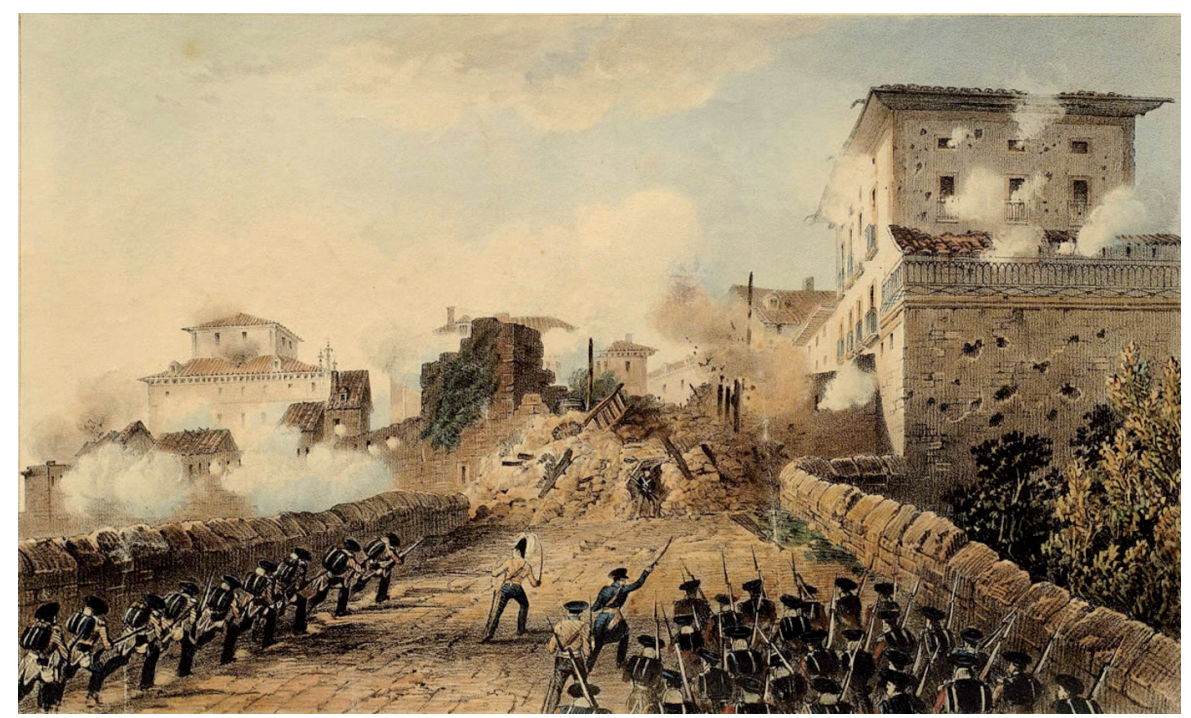

Figura 4. Thomas Lyde Hornbrook: Puerta de Behobia de Irún, bajo el ataque de las fuerzas Reales Irlandesas, el 17 de mayo de 1837

\subsection{Juan Antonio Prol, nuevamente Maestro-organista interino}

Al haber tenido que abandonar forzosamente su puesto Agustín Echaide en mayo de 1837, en septiembre de aquel mismo año, Juan Antonio Prol solicita la plaza de Organista, petición que es aceptada por el Ayuntamiento ${ }^{72}$. Las siguientes noticias referentes a Prol están relacionadas con su remuneración y los complementos que ésta lleva aparejados:

" 6 . A demanda del Organista don Juan Antonio Prol se resolvió darle para el consumo de su casa sesenta fajos de leña, quedando al efecto encargado el Regidor Baleurategui"’33.

72 Acta de 11 de Septiembre de 1837, AMI, vol. 82, fol. 53.

73 Acta de 25 de Octubre de 1837, AMI, vol. 82, fol. 63. 
"Igualmente se mandó abonar al Organista Prol 320 reales vellón por la pensión de cuidar y regir los dos relojes de la villa. Con lo cual dio fin esta sesión"74.

En 1839 Prol solicita la presencia de dos tiples (costumbre instaurada tiempo atrás) para el acompañamiento del canto polifónico que se interpretaba en las funciones de la Iglesia de Santa María del Juncal:

"Se hizo lectura de un memorial de don Juan Prol, Organista de la Iglesia Parroquial de la villa solicitando la habilitación de dos tiples, que siempre ha tenido, para acompañar en el canto de órgano y coro. En su visita acordaron los señores pasase esta solicitud a informe del Mayordomo de la Iglesia"75.

Después de dos años desempeñando interinamente la plaza de Organista de Santa María del Juncal, Juan Antonio Prol solicita se le otorgue la posesión de la plaza en propiedad "en atención a sus méritos y servicios". Contraviniendo la costumbre de proveer la plaza mediante la pertinente convocatoria y correspondientes ejercicios de oposición, el Ayuntamiento acuerda concederle a Prol la citada posesión, argumentando la adhesión de Prol "a la causa del trono constitucional" y a las "persecuciones inauditas" que ha padecido. También se alude al hecho de haber servido la misma plaza entre los años 1818 y 1823 , año este último en que Echaide ganó la oposición, como vimos anteriormente ${ }^{76}$. Al poco tiempo, el Consistorio irunés se prepara para otorgar la escritura de posesión de la plaza:

"Se dispone igualmente otorgar la competente escritura a don Juan Antonio Prol por haber obtenido la plaza en propiedad de Organista de esta villa y se da la comisión para efectuarlo a don Ramón de Echeandía poniéndose de acuerdo con el interesado Prol"77.

A pesar de que se prorrogó la interinidad de Prol no faltaron candidatos que se interesaron por la organistía de Irún: es el caso del vergarés León Vidaburu, quien desde Bilbao se ofrece al Consistorio irunés para ejercer el cargo de Organista pues "ha llegado a entender se halla vacante la plaza de organista de la parroquia de esa villa y aspira a obtenerla". Destaca Vidaburu entre sus méritos el poseer conocimientos de canto, su formación con el maestro de la Catedral-Basílica de Bilbao así como su adscripción política ("El afecto del exponente a la causa de la reina") y el haber sido uno de los defensores de Vergara en septiembre de 1834 y de San Sebastián en junio de 1835; incluso está dispuesto Vidaburu a desempeñar el cargo de forma interina: sin embargo, tal como vimos anteriormente, Prol se había adelantado ${ }^{78}$. Como podemos observar, la postura política que adoptan los músicos durante la época de la Primera Guerra Carlista (1833-1840) y su participación activa a favor del bando realista o cristino (denominado así por su apoyo a la reina regente María Cristina de Borbón-Dos Sicilias) o del bando carlista es aducido como un

74 Acta de 31 de Diciembre de 1838, AMI, vol. 82, fol. 163.

75 Acta de 6 de Febrero de 1839, AMI, vol. 82, fol. 172.

76 Acta de 26 de Octubre de 1839, AMI, vol. 82, fol. 230.

77 Acta de 15 de Noviembre de 1839, AMI, vol. 82, fol. 235

78 Documentación referente al nombramiento y servicios de organista, AMI, Sección E, Negociado 4, Serie II, Libro $n^{\circ} 4$, Expediente $n^{\circ} 3$, Asunto: Relaciones con las autoridades eclesiásticas, 1773-1853. 
mérito añadido a la preparación o experiencia puramente musical, pudiendo ser determinante a la hora de obtener un puesto de trabajo remunerado ${ }^{79}$.

Aunque el Ayuntamiento abonaba a su Organista la parte principal de su salario, otra parte era devengada por la propia iglesia. Dadas las dificultades económicas por las que en algunas ocasiones atravesaba la Iglesia de Santa María del Juncal, no siempre era posible que la mencionada iglesia pudiese cumplir con sus compromisos o bien se produjeran retrasos en los pagos, tal como ocurre en marzo de 1841. Por todo ello, Prol recurre al Ayuntamiento para que el Mayordomo de la fábrica de Santa María del Juncal, a la sazón José Joaquín de Olazábal, le abone los atrasos, que ascienden a la nada despreciable cifra de 907 reales. Gracias a este memorial de Prol conocemos que sus dos hijos están cantando en la Capilla en calidad de tiples:

"Se hizo lectura de un memorial de don Juan Antonio Prol, Organista de la Iglesia Parroquial de esta villa, en el que suplica al Ayuntamiento se sirva mandar se le paguen por el Mayordomo de la fábrica, don José Joaquín de Olazábal Arbelaiz, novecientos siete reales vellón que le faltan, a saber quinientos treinta y tres para completo pago de su asignación perteneciente al año último de mil ochocientos cuarenta, y trescientos sesenta y cuatro por la correspondiente a sus dos hijos que asisten al coro en calidad de tiples, en los tres años de mil ochocientos treinta y ocho, treinta y nueve y cuarenta, con rebaja de la tercera parte de los dos primeros años, y enterado el Ayuntamiento de su contenido, acordó pasar a informe del Mayordomo, don José Joaquín Olazábal Arbelaiz"80.

El estado del órgano de Santa María del Juncal vuelve a ser motivo de preocupación, por lo que, al igual que ocurriera durante los magisterios de Balzola y de Echaide, Prol solicita la urgente reparación de los fuelles a comienzos de marzo del año 1842:

" $20^{\circ}$. Se leyó un memorial del Organista, don Juan Antonio Prol, solicitando se le autorice para proceder a la composición de los fuelles del órgano y se acordó acceder a su solicitud informándose primero si hay fondos de la fábrica" ${ }^{\prime 1}$.

Transcurridos cinco años desde que se suscribiera la última escritura de conducción del órgano, Prol solicita al Ayuntamiento la renovación de dicha escritura a partir del uno de enero de 1845 y hasta el 31 de diciembre de 1849:

" $2^{\circ}$. Se hizo lectura de un memorial presentado por don Juan Antonio Prol solicitando la continuación en la plaza de Organista de esta villa y se acordó renovarle la escritura anterior por otros cinco años. Con lo que se dio fin a esta acta que firmaron los señores que se hallaron presentes" ${ }^{\prime 2}$.

79 Para más información sobre este periodo histórico, véase la obra dirigida por JOVER ZAMORA, 1988.

80 Acta de 3 de Marzo de 1841, AMI, vol. 83, fol. 79r.

81 Acta de 9 de Marzo de 1842, AMI, vol. 84, fol. 29.

82 Acta de 8 de Diciembre de 1844, AMI, vol. 86, fol. 202v. 
Al haberse conservado la escritura de renovación ${ }^{83}$, conocemos las obligaciones que el Maestro de capilla-Organista de Irún contraía, entre las cuales destacaríamos las siguientes:

a) Tocar el órgano "así en misa mayor como en vísperas, concurriendo personalmente a todas las funciones de iglesia, tanto en días de precepto como en las de labor”. En caso de ausencia, debe solicitar la oportuna autorización al Ayuntamiento, "en cuyo caso deberá poner sustituto capaz por su cuenta y cargo para el tiempo que dure su ausencia"; la misma norma rige en caso de enfermedad, asumiendo el propio interesado los gastos derivados de tal sustitución. b) Otro apartado de obligaciones está relacionado con la enseñanza musical, concretamente la de impartir lecciones gratuitas de música durante dos horas al día a todos los niños iruneses que así lo quisieran "sin que pueda exigir cosa alguna por este trabajo". c) El Maestro de Capilla-Organista debe asimismo intervenir en las funciones de la "Música de aficionados" tocando un instrumento sin especificar. d) Por último, se obligaba a Prol al cuidado del órgano, "sin que por defecto suyo resulte el menor daño, [so] pena de ser responsable a la subsanación de todos los perjuicios".

Según la mencionada escritura, su salario anual se eleva a 3900 reales de vellón, los cuales son obtenidos de la contribución recaudada para las actuaciones del culto de la villa, correspondiendo 900 reales al Cabildo, como vimos anteriormente.

En enero de 1845 se recibió una carta del anterior Organista de Irún, Agustín Echaide, quien, a una carta del Alcalde, respondía que las cuentas encontradas en los caños del órgano no correspondían a los conceptos que se le adeudaban pues aún le quedaba por percibir parte de los derechos del vino y del aceite que le correspondían:

" $10^{\circ}$. Se hizo lectura de un oficio dirigido por don Agustín Cayetano de Echaide al señor Alcalde, en contestación al que éste le pasó con fecha nueve del corriente, participándole haberse encontrado en los caños del órgano varios cuadernos de apuntes de la recaudación de derechos municipales de esta villa, año de mil ochocientos treinta y siete, en donde resulta haber ingresado en poder de dicho Echaide la cantidad de 15643 reales y 5 céntimos y manifiesta que aunque esta cantidad figura en dichos cuadernos como ingresado en su poder, no había recibido cuando se ausentó, una parte de los derechos del vino y aceite despachados en la Mondiga; y con motivo del asalto que sufrió esta villa en dicho año, dejó abandonados sus intereses juntamente con los fondos municipales que obraban en su poder y quedaron enterados" $"$.

Después de la última intervención de marzo de 1842, en febrero de 1845 debe someterse el órgano a una nueva reparación, en esta ocasión más profunda que la anterior ya que el coste alcanzó la cifra de 1807 reales:

“ 3 Se vio la cuenta presentada por Mayordomo de la fábrica de la Iglesia Parroquial que importa 1807 reales y 27 céntimos por los gastos ocasionados en la reparación del órgano de esta iglesia; y se acordó

83 Documentación referente al nombramiento y servicios del Organista Juan Antonio Prol, AMI, Sección E, Negociado 4 , Serie II, Libro $n^{\circ} 4$, Expediente $n^{\circ} 4$, Asunto: Relaciones con las autoridades eclesiásticas, 1841-59.

84 Acta de 27 de Enero de 1845, AMI, vol. 86, fol. 10v. 
expedir un libramiento de dicha cantidad a favor del Mayordomo para que se haga cobro de los fondos que obren en su poder pertenecientes a la fábrica" ${ }^{85}$.

Cinco meses después los fuelles del órgano deben ser nuevamente restaurados, labor efectuada por un tal "Kneip":

"Se vio la cuenta de D. Kneip de cuarenta y seis reales por la compostura de los fuelles del órgano de la Iglesia Parroquial de esta villa y se acordó expedir el correspondiente libramiento contra la fábrica de la misma" $"$.

Al acercarse la fecha de expiración de la escritura del Organista, otorgada en 1845, tal como vimos anteriormente, Prol solicita una nueva renovación. Recordemos al respecto que, al no haber mediado oposición previa, el actual Organista se veía obligado a renovar periódicamente la escritura, es decir, asumía la plaza de forma interina mientras que los organistas que habían accedido mediante oposición, ejercían la organistía "por el término de su vida". En esta ocasión, Juan Antonio Prol propone dos modificaciones por lo que respecta a sus deberes profesionales: la anulación de la obligación de tener que tocar un instrumento durante las funciones de la "Música de aficionados" y en segundo lugar, la reducción a seis de los alumnos que recibían clases gratuitas del Organista de la villa:

" $2^{\circ}$. Se hizo lectura de otro memorial presentado por don Juan Antonio Prol pidiendo que se renueve la escritura en su favor para el desempeño de la plaza de Organista de esta villa, suprimiendo la comisión que anteriormente tenía de acudir a tocar un instrumento en la Música marcial y de que haya de enseñar la música a todos los muchachos que quieran en el pueblo, reduciendo la obligación solamente a seis muchachos, y el Ayuntamiento acordó pasar su memorial a los señores Arrascaeta y Rodríguez para que propongan las condiciones que les parezcan para el otorgamiento de dicha escritura" ${ }^{97}$.

La propuesta de Prol es estudiada por los concejales Arrascaeta y Rodríguez, quienes, además, examinan las condiciones para otorgar las plazas de cirujano y médico de Irún. Aceptan la petición de Prol de prórroga de su escritura de organista por otros cinco así como su solicitud de enseñar sólo a seis muchachos que designe el propio Ayuntamiento pero no se refieren a la obligatoriedad para el organista de participar en las funciones de la "Música de aficionados", por lo que cabe deducir que Prol tuvo que seguir interviniendo en las citadas funciones ${ }^{88}$.

En julio de 1855 se conoce el presupuesto municipal para el culto, en el que la partida asignada para la "composición del órgano" se destina sin embargo a "la construcción de un nuevo cementerio, eso

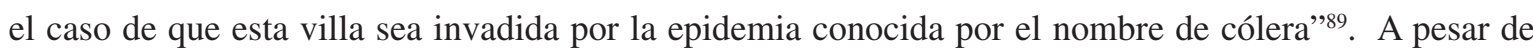

85 Acta de 22 de Febrero de 1845, AMI, vol. 86, fol. 15r.

86 Acta de 22 de Julio de 1846, AMI, vol. 87, fol. 67.

87 Acta de 1 de Octubre de 1849, AMI, vol. 88, fol. 113r.

88 Acta de 5 de Diciembre de 1849, AMI, vol. 88, fol. 121r-v.

89 Acta de 21 de Julio de 1855, vol. 91, AMI, fol. 33v-34r. 
esta decisión, en noviembre de aquel mismo año se acomete una profunda reforma del órgano a cargo de Miguel Roques y Hermenegildo Gómez, cuyo informe es taxativo sobre la delicada situación del citado instrumento ${ }^{90}$ : así por ejemplo, ambos organeros detectan los siguientes defectos:

1) Deterioro de cuatro fuelles de palancas "incapaces de surtir el viento necesario al órgano por lo mucho deteriorados y apolillados que se hallan"91.2) La mayor parte de los registros interiores "se hallan inútiles o mudos por el mucho polvo que se ha introducido por sus tubos, por lo que es inevitable un desmonte o limpieza general"92. 3) La mayoría de los ejes o guías de tornantes se encuentran oxidados "por ser de hierro", ante lo cual se propone su sustitución por unos de latón ${ }^{93}$. 4) Los citados organeros aconsejan también que los caños de los registros de lengüetería "deben lengüarse" 94.

Como solución, los citados organeros proponen la construcción de dos grandes fuelles "llamados a doble pompa, como los que se hicieron para el órgano de Santiago de Chile, construido por los mismos" así como otros dos más pequeños "llamados ventiladores para surtir el viento a los principales colocados con su balancín"95. Asimismo se llevaría a cabo una limpieza general de todos los caños del órgano, incorporando a éstos los canales, lenguas y moldes "que se crea necesario"96. Proponen la inclusión de un nuevo registro, denominado tembleque suave, el cual, según Roques y Gómez, "es indispensable para tocar el de la voz humana" y por último se llevaría a cabo una partición y afinación, gracias a lo cual "sus voces armoniosas podrán competir con cualquier otro de su clase" ${ }^{97}$. El presupuesto, que asciende a 2500 reales, es aceptado por el Consistorio irunés, el cual nombra una comisión compuesta por el concejal Joaquín Olazábal y el propio Juan Antonio Prol para la realización de la reforma. Los trabajos de reforma finalizaron en marzo de 1856 a satisfacción del Consistorio irunés, quien además muestra su gratitud José Nicolás de Aguinaga por haber costeado los gastos de un teclado nuevo para el órgano:

"6․ Se acordó dar su nombre al Ayuntamiento las más expresivas gracias a doña María Vicenta de Olazábal y don José Nicolás de Aguinaga: a la primera por haber costeado los damascos que se han colgado en las paredes inmediatas del altar mayor con sus correspondientes zócalos de madera y al segundo por haber costeado también el teclado nuevo del órgano.

$11^{\circ}$. Se hizo presente que se había terminado ya el arreglo del órgano de la Iglesia Parroquial de esta villa, habiendo ejecutado a satisfacción de los comisionados los trabajos a que se comprometieron los organeros y que además de las obras convenidas habían ejecutado otras varias, por las que la comisión las consideraba acreedores a una gratificación de quinientos reales, además de los dos mil y quinientos en que se hizo el ajuste y el Ayuntamiento acordó expedir un libramiento de tres mil reales vellón a favor de los referidos organeros" $" 98$.

90 Documentación referente al nombramiento y servicios del Organista Juan Antonio Prol, op. cit.

91 Acta de 15 de Noviembre de 1855, AMI, vol. 91, fol. 66v.

92 Acta de 15 de Noviembre de 1855, AMI, vol. 91, fol. 67r.

93 Ibidem.

94 Ibidem.

95 Ibidem.

96 Ibidem.

97 Acta de 15 de Noviembre de 1855, AMI, vol. 91, fol. 67v.

98 Acta de 5 de Marzo de 1856, AMI, vol. 91, fol. 92r. 
Durante el magisterio de Prol se procede al nombramiento de Sochantre de la Iglesia de Santa María del Juncal en la persona de Rafael Salcedo, maestro de escuela y miembro de la "Música marcial" de Irún, si bien se puntualiza que no se trata de un "plaza perpetua": además de responsabilizarse de la interpretación del canto gregoriano durante las misas mayores y vísperas de los días festivos, deberá sustituir al Organista "en sus ausencias y enfermedades":

"5\%. Se hizo lectura de un memorial presentado por don Rafael Salcedo, vecino de esta villa, manifestando que desea ocuparse en el servicio del coro en clase de Sochantre en los días festivos, que son los que su profesión le permite también suplir la falta de Organista, y pide con este motivo, que se le confiera el empleo que solicita, señalándole el sueldo que tenga por conveniente. El Ayuntamiento, en vista de dicho memorial, nombró al referido Salcedo por Sochantre de la Iglesia Parroquial de esta villa con el sueldo de mil reales anuales, pagaderos de los fondos de la contribución del culto, haciendo constar sin embargo en este acta que con este nombramiento no se crea una plaza perpetua de Sochantre sino que el nombramiento se hace por los servicios que dicho Salcedo está prestando con su profesión de Maestro de escuela a diferentes familias que educan con él sus hijos y por su puntual asistencia a la Música marcial de esta villa; y se le pone por condición de que haya de pertenecer a dicha música y acudir al coro a cantar en las misas mayores y vísperas de los días festivos y suplir la falta del Organista en sus ausencias y enfermedades, en los casos en que el señor Alcalde de esta villa lo disponga" 99 .

Tal como hemos visto anteriormente, cada cinco años el Organista, dada su situación de provisionalidad, se ve en la necesidad de solicitar al Ayuntamiento la renovación de su escritura o contrato como Organista, a lo que el Consistorio accede ${ }^{100}$.

Una de las preocupaciones habituales de los Maestros de Capilla-Organistas de Irún es contar con buenas voces blancas, por lo que es frecuente la petición por parte de éstos en este sentido:

" $4^{\circ}$. Se hizo lectura de un memorial presentado por don Juan Antonio Prol, Organista de la Iglesia Parroquial de esta villa, manifestando que se halla escaso de tiples para el coro y suplicando que el Ayuntamiento los escoja de las mejores cualidades para que aprendan a cantar; y el Ayuntamiento nombró una comisión compuesta de los señores don Joaquín de Olazábal y don José Joaquín de Olazábal Arbelaiz para elegir los dos tiples que se necesiten, y proponer al Ayuntamiento las variaciones que se crean convenientes hacer en el coro" 101 .

Las relaciones de Prol con el Ayuntamiento en 1859 no parecen pasar por el mejor momento debido a una ausencia no permitida del Organista ${ }^{102}$ así como a los insultos vertidos por éste hacia el Alcalde y uno de los concejales de la corporación, José Joaquín Olazábal, el cual aprovecha el agravio sufrido para recordar el carácter interino de la plaza de Juan Antonio Prol y que el verdadero poseedor legítimo de

99 Acta de 8 de Enero de 1856, AMI, vol. 91, fol. 81r-v.

100 Acta de 6 de Mayo de 1857, AMI, vol. 91, fol. 163v-164r.

101 Acta de 16 de Febrero de 1859, AMI, vol. 92, fol. 10r.

102 Ausencia que tendrá consecuencias imprevisibles para Prol ya que acabarán con su expulsión del magisterio en Irún en junio de 1869, después de una larga querella que analizaremos a continuación. 
dicha plaza era Agustín de Echaide. Por todo ello, el Consistorio acuerda dirigirse a Echaide por carta para preguntarle si después del Convenio de Vergara ${ }^{103}$ ha efectuado alguna reclamación con el fin de recuperar su antiguo puesto ${ }^{104}$. La falta disciplinaria cometida por Juan Antonio Prol servirá de excusa para plantear en abril de 1859 la rescisión del contrato de Prol y la posible vuelta como Organista de Agustín de Echaide, el cual, el 1 de abril de aquel año remite una carta desde la ciudad francesa de Mont de Marsan a José Ignacio Orbegozo, Alcalde de Irún, informando que después del Convenio de Vergara intentó recuperar el puesto de Organista pero el Alcalde de aquella época (a la sazón, Miguel Camino) le negó esta posibilidad ${ }^{105}$. Once día después envía una segunda carta al Consistorio ${ }^{106}$ solicitando su regreso a su anterior puesto, propuesta que causa una profunda división entre los partidarios de respetar la escritura otorgada a Prol (aún vigente) y los que, con el Alcalde al frente, opinan que Echaide tiene derecho a retomar su antigua responsabilidad musical en Irún, postura esta última apoyada por uno de los abogados consultados, el cual "está en su derecho el citado Echaide al pretender se le permita volver a servir dicho destino dejando sin efecto la escritura de treinta de julio de 1857 otorgada a favor de don Juan Antonio Prol que no puede tener sino el carácter de interino". Un grupo de concejales, sin embargo, son de la opinión que "no puede despojársele a Prol ni reponer al señor Echaide en la plaza que solicita hasta tanto que se cumpla el término prefijado en la última escritura". Finalmente tras la correspondiente votación se impuso por nueve votos a cinco la opción favorable a Echaide, quien "tiene derecho a que se le reponga en la plaza de Organista de esta villa... y se acordó dar posesión al señor Echaide a las ocho horas del día de mañana de la plaza de Organista de esta villa" ${ }^{107}$. Al mismo tiempo que se recibía la carta de Echaide, Juan Antonio Prol se dirigía a su vez al municipio de Irún para defender sus derechos y comunicar que desde "el año de 1854 estoy nombrado Organista de la misma [Iglesia Parroquial de Irún] por tiempo de cinco años y que creo que hasta concluir este plazo no podía tomar Vuestra Señoría semejante acuerdo [conceder la plaza de Organista a Echaide]", pese a lo cual Prol entrega la llave del órgano, ni sin advertir que "trato de reclamar donde corresponda contra el acuerdo de Vuestra Señoría y contra la posesión que se trata de dar al indicado señor Echaide"108. Quizá en relación a la situación que está viviendo Juan Antonio Prol, el bajonista Pedro Prol decide dimitir de su puesto en la Capilla musical de Santa María del Juncal ${ }^{109}$.

El día 12 de abril de 1859, Agustín de Echaide es repuesto en su cargo de Organista de Irún, 22 años después de haberse visto obligado a abandonar el puesto. Al acto, celebrado en el coro de la Iglesia Parroquial de Santa María del Juncal a partir de las ocho de la mañana, asisten el Alcalde irunés, José Ignacio Orbegozo, el Concejal José Joaquín Olazábal, y el Secretario, en representación del Ayuntamiento, ade-

103 El Convenio de Vergara fue suscrito el 29 de agosto de 1839 entre el general Espartero, representante del bando isabelino, y varios representantes del general carlista Maroto, dando fin de esta manera a la Primera Guerra Carlista. El 31 de mayo de aquel año, ambos generales refrendaron el acuerdo con su célebre abrazo, por lo que dicho Convenio se conoció asimismo bajo la denominación de Abrazo de Vergara. Para más información sobre la Primera Guerra Carlista, consúltese EXTRAMIANA, 1979.

104 Acta de 30 de Marzo de 1859, AMI, vol. 92, fol. 18r.

105 Documentación referente al nombramiento y servicios del Organista Juan Antonio Prol, op. cit.

106 Ibidem.

107 Acta de 11 de Abril de 1859, AMI, vol. 92, fol. 19v-20v.

108 Documentación referente al nombramiento y servicios del Organista Juan Antonio Prol, op. cit.

109 Acta de 19 de Abril de 1859, AMI, vol. 92, fol. 25v. 
más del propio Echaide. Una vez leído el acuerdo municipal de restituir en el cargo a Echaide así como la protesta emitida por Juan Antonio Prol y su intención de recurrir dicho acuerdo, Echaide "abrió en el acto el órgano y tocó en el acto varias piezas e hizo otras señales y actos de verdadera y legítima posesión de Organista de la Iglesia Parroquial de esta villa"110.

Sin embargo, la protesta de Prol surge efecto: al día siguiente de la toma de posesión de Echaide, el Gobernador Civil de la provincia de San Sebastián solicita explicaciones al Ayuntamiento de Irún y ordena paralizar la posesión de la organistía por parte de Echaide: “...suspendiendo todo procedimiento, se sirva Vuestra Señoría informarme cuanto se le ofrezca y parezca, manifestando con claridad las razones en que se ha fundado Vuestra Señoría para destituir de su empleo al exponente y llamar en reemplazo a don Agustín Echaide" ${ }^{111}$. Finalmente y después de un largo proceso judicial en el que intervienen diferentes instancias, el Consejo Provincial de Guipúzcoa emite sentencia el 23 de junio de $1860^{112}$, cuyas dos conclusiones principales, una vez estudiados todos los antecedentes, pueden resumirse en los siguientes apartados:

a) Se declara nula la escritura de Prol como Organista de Santa María del Juncal "por la que el Ayuntamiento de Irún confirió a don Juan Antonio Prol para cinco años la plaza de Organista de la Iglesia Parroquial de aquella villa". b) Permite al Ayuntamiento la convocatoria de la plaza de Organista pues le compete "la facultad de proceder desde luego a su provisión en la forma que determinan sus ordenanzas municipales, sin obligación de indemnizar a dicho don Juan Antonio Prol los daños y perjuicios que puedan originársele por la negación del contrato". La sentencia es dada a conocer en el pleno municipal del 18 de julio de 1860 y se decide invitar a Prol a que siga ocupando interinamente la plaza de Organista hasta que no se verifique la oposición y el consiguiente nombramiento oficial de su sucesor al frente de la organistía de Santa María del Juncal:

" $13^{\circ}$. Se hizo lectura de la sentencia dictada por el Consejo Provincial en el pleito que esta villa ha seguido con don Juan Antonio Prol, en cuya sentencia se declara nula y de ningún valor la escritura en cuya virtud está sirviendo dicho Prol la plaza de Organista de esta villa, y en su vista el Ayuntamiento declaró vacante dicha plaza, acordando que se provea a oposición conforme se previene en las ordenanzas de esta villa, fijando antes las condiciones que han de servir para la oposición, para la cual se nombró una comisión compuesta de los señores Alcalde y concejales Olazábal y Olazábal Arbelaiz, y vecinos don Policarpo Balzola, don Melitón Romery y don Juan María Yndart. Al propio tiempo se acordó poner este acuerdo en conocimiento del citado Prol, invitándole a que continúe desempeñando interinamente con el mismo sueldo y emolumentos hasta que se haga la oposición" $" 13$.

La propuesta municipal de continuar desempeñando provisionalmente la función de Organista de Irún es aceptada por Juan Antonio Prol:

110 Documentación referente al nombramiento y servicios del Organista Juan Antonio Prol, op. cit.

111 Ibidem.

112 Ibidem.

113 Acta de 18 de Julio de 1860, AMI, vol. 92, fol. 118r. 
" $10^{\circ}$. Se hizo lectura de un oficio dirigido por don Juan Antonio Prol, manifestando que queda en desempeñar el cargo de Organista, interin se provea esta plaza en propiedad en los términos que está mandado; y el Ayuntamiento quedó enterado"114.

Una de las últimas ocasiones en que las actas se referirán a Juan Antonio Prol en calidad de Organista de Irún es en relación a la celebración de la Misa mayor en julio de $1860^{115}$.

\subsection{Oposiciones en 1860 y elección de Rufino Echaide}

A mediados de agosto de 1860 año se trata en el transcurso de una sesión municipal sobre las condiciones relativas a la convocatoria de la oposición al magisterio-organistía de Santa María del Juncal, entre las que destaca que la edad de los aspirantes debe oscilar entre los 24 y los 40 años de edad, nombrándose como censor a Cándido Aguayo, Organista de la Iglesia Parroquial de Santa María en Tolosa ${ }^{116}$. Según la documentación relativa a Rufino Echaide y conservada en el Archivo Municipal de Irún bajo el título de Documentación referente al nombramiento y servicios del organista D. Rufino Echaide, en la misma sesión municipal se acuerda dar a conocer la convocatoria de oposición en diferentes medios impresos, tales como el Boletín Oficial, la Gaceta de Madrid, la Gaceta Musical y en un periódico de Bilbao con el siguiente enunciado: "Hallándose vacante la plaza de Maestro de Capilla y Organista de esta villa de Irún, se proveerá a oposición bajo las condiciones que estarán de manifiesto en la Secretaría del Ayuntamiento habiéndose fijado para los ejercicios que se han de hacer en la misma parroquia el día tres de octubre próximo y siguientes". Asimismo se especifica que la dotación correspondiente a la plaza de Organista de Irún asciende a la cantidad de 5500 reales anuales, "satisfechos de sus fondos con más los emolumentos y subvenciones acostumbradas". Por otra parte los candidatos deben presentar sendas certificaciones que acrediten su conducta moral, expedidas tanto por el Alcalde como por el párroco de su respectivo domicilio ${ }^{117}$.

A comienzos de agosto de 1860 Cándido Aguayo respondió al Consistorio irunés aceptando la función de maestro examinador: "acepto dicho cargo de examinador y prometo corresponder dignamente a la confianza que V. S. ha depositado en mí, quedando altamente reconocido al favor que en esta sesión V. S. me ha dispensado" 118 .

A las oposiciones, cuyo comienzo había sido establecido para el tres de octubre, se presentaron seis candidatos, según se desprende del acta municipal de la sesión celebrada el 23 de septiembre de 1860:

114 Acta de 1 de Agosto de 1860, AMI, vol. 92, fol. 121r.

115 Acta de 1 de Agosto de 1860, AMI, vol. 92, fol. 122v.

116 Acta de 14 de Agosto de 1860, AMI, vol. 92, fol. 123v. Sobre este músico, véase LÓPEZ-CALO, LEGASPI, 1999, vol. 1: 102-103.

117 Documentación referente al nombramiento y servicios del organista D. Rufino Echaide, AMI, Sección E, Negociado 4, Serie II, Libro $\mathrm{n}^{\circ} 4$, Expediente $\mathrm{n}^{\circ}$ 5, Asunto: Relaciones con las autoridades eclesiásticas, 1860-75 y 1888.

118 Ibidem. 
Rufino Echaide, Estanislao Sancho, Santos Miranda, José Agustín Isasa, Modesto de Letamendía y José Antonio Santesteban. Sin embargo, algunos de los candidatos no presentaron toda la documentación requerida, ante lo cual el Consistorio irunés se dividió: unos concejales eran partidarios de no admitir a los candidatos que no cumplían con las condiciones de la convocatoria en el sentido de presentar la certificación de buena conducta mientras que otro grupo de concejales eran de la opinión que se les admitiese $^{119}$. A causa de esta disparidad de criterios, el Alcalde decidió remitir el 23 de septiembre de 1860 un oficio al Gobernador Civil de la provincia en petición de instrucciones. Al día siguiente respondió el Gobernador Civil, quien acepta que puedan presentarse todos los candidatos pese a no haber entregado la documentación exigida de forma completa ya que "conviene mucho a un Ayuntamiento, al buen servicio del vecindario así como al del culto de la Iglesia, que en lugar de disminuir aumente el número de los aspirantes a la citada plaza pues, claro está, que en este último caso podrá hacerse más ventajosamente la elección y podrá también recaer ésta en la persona en quien se reconozca mayor aptitud"120. Conocida la postura favorable del Gobierno Civil de Guipúzcoa, el Ayuntamiento decide aceptar las candidaturas de los seis opositores ${ }^{121}$.

Antes de proceder al examen de los seis candidatos, Aguayo juró su cargo de maestro examinador de las oposiciones a la organistía de Irún el 3 de octubre de 1860: “...dijo que acepta el nombramiento de examinador y en manos de su merced [el Alcalde de Irún] juró en legal forma desempeñar el cargo bien y fielmente, y de hacer la elección de Organista entre los seis opositores, en el que fuere de la mayor inteligencia y capacidad en el manejo y composición" 122.

El incomprensible e inusual veredicto o censura de Cándido Aguayo sobre los ejercicios realizados por cada uno de los cinco candidatos, después de haber "oído y examinado con la mayor escrupulosidad y detención los ejercicios de órgano y composición hechos por los opositores, teniendo presente los extremos que abrazan facultades"123 va a causar un grave quebranto a la Capilla musical de Irún al elegir en primer lugar a tres candidatos (Rufino Echaide, José Antonio Santesteban y Santos Miranda) pero sin concederles una puntuación pues los tres "tienen los conocimientos necesarios y se hallan con igual mérito para obtener la plaza a que se muestran aspirantes", por lo que dejó en manos del Consistorio municipal la elección última del Organista de Santa María del Juncal, decisión que acarreará la división del Ayuntamiento, como tendremos la oportunidad de comprobar a continuación. Este recoge en el acta municipal del 7 de octubre de 1860 la recepción de la censura de Aguayo, ocasión que el Alcalde aprovecha para comunicar la preocupación del Gobernador Civil de la provincia por la falta de asistencia de los concejales a las sesiones plenarias del Ayuntamiento ${ }^{124}$.

El propio maestro examinador, Cándido Aguayo, se presentó en la reunión del Consistorio del citado día 7 de octubre para hacer acto de entrega de su dictamen sobre el resultado de las oposiciones, cele-

119 Acta de 23 de Septiembre de 1860, AMI, vol. 92, fol. 130v-131r.

120 Documentación referente al nombramiento y servicios del organista D. Rufino Echaide, op. cit.

121 Acta de 26 de Septiembre de 1860, AMI, vol. 92, fol. 131v-132r.

122 Documentación referente al nombramiento y servicios del organista D. Rufino Echaide, op. cit.

123 Ibidem.

124 Acta de 7 de Octubre de 1860, AMI, vol. 92, fol. 134v. 
bradas entre el tres y el seis de octubre ${ }^{125}$. Ante la falta de definición sobre el vencedor de la oposición al haber situado Aguayo a tres candidatos en igualdad de condiciones, surgen las primeras desavenencias y así, el Segundo Teniente de Alcalde, Julián Rodríguez, propone "que se nombrara otro Maestro para que examinase de nuevo a don Santos Miranda, don Rufino Echaide y don José Antonio Santesteban, que figuran en primera letra, y viendo entonces cuál de estos era el mejor, se procediera a su elección" mientras que, por el contrario un grupo de concejales "manifestaron que no era necesario el nuevo examen que se proponía y que estaba en el derecho del Ayuntamiento el poder elegir a cualquiera de los que figuran en primera letra puesto que el Maestro examinador nombrado por el Ayuntamiento los ha clasificado de igual mérito, con conocimientos necesarios para obtener la plaza a que se muestran aspirantes". Ante tal disparidad de criterios, el propio Segundo Teniente de Alcalde propuso que se consultase a otras personas para intentar resolver el problema causado por la forma de examinar de Aguayo o bien que se eligiese por sorteo a uno de los tres elegidos "en primera letra": ambas opciones fueron rechazadas por la mayoría de concejales del Ayuntamiento de Irún. Finalmente "se procedió a votar sobre si la elección se había de hacer por votación o por suerte": salió como más votada la primera alternativa, ante lo cual, un grupo de cinco concejales abandonó la sesión municipal pese a la prohibición expresa del Alcalde. Efectuada la votación, sin la presencia de los cuatro cinco concejales ausentes, fue elegido Rufino Echaide, al que le favoreció su ascendencia irunesa y el hecho de haber sido hijo de un antiguo Organista de la Capilla musical de Santa María del Juncal: "Y en vista de este resultado manifestaron que quedaba elegido el indicado don Rufino Echaide como Organista y Maestro de Capilla de la Iglesia Parroquial de esta villa, declarando todos lo que a él le han votado que la elección han hecho en su favor por ser hijo de este pueblo". En la misma sesión municipal del 10 de octubre se confirma la elección de Rufino Echaide como nuevo Organista de Santa María del Juncal ${ }^{126}$ mientras que la toma de posesión tuvo lugar el mismo día 10 de octubre de 1860 cuando el Alcalde, José Ignacio Orbegozo, "le entregó la llave del órgano, autorizándole para en nombre del Ayuntamiento para que tome posesión de la plaza de Organista y Maestro de Capilla de esta Parroquia, que dicho señor Alcalde le daba en el acto quieta y pacíficamente sin oposición de nadie" 127.

\section{CONCLUSIONES}

La vida musical de la ciudad guipuzcoana de Irún ha girado desde el siglo XVI en torno a la capilla musical de la iglesia parroquial de Santa María del Juncal, que dispuso desde sus orígenes de un grupo de cantores e instrumentistas para solemnizar el culto litúrgico y participar en todo tipo de manifestaciones religiosas, como es el caso de las procesiones. Al depender del patronazgo municipal, característica típica de las capillas musicales vascas, no se vio tan afectada como otras capillas españolas por la decadencia de

125 Ibidem.

126 Acta de 10 de Octubre de 1860, AMI, vol. 92, fol. 136r.

127 Documentación referente al nombramiento y servicios del organista D. Rufino Echaide, op. cit. 
la música religiosa española en el siglo XIX, debida a las diferentes desamortizaciones o a la promulgación del Concordato de 1851. Así pues, se percibe que durante la primera mitad del siglo XIX la capilla musical irunesa de Santa María del Juncal experimenta una etapa dorada gracias a la presencia al frente del magisterio de autores tan significativos como Miguel de Balzola Garamendi o Agustín de Echaide. Por el contrario, la capilla de Irún sí se vio afectada por los avatares políticos de la época -especialmente las Guerras Carlistas-, que convulsionaron en distintas etapas la evolución y composición de dicha capilla, siendo las autoridades municipales, provinciales e incluso judiciales las encargadas de dirimir los diferentes conflictos que por causas políticas se originaron en el seno de la capilla irunesa.

Este artículo ha demostrado cómo una capilla parroquial de provincias desempeñó un papel esencial en la vida musical de una pequeña ciudad en la España de finales del siglo XVIII y primer mitad del XIX, papel que no se limitó exclusivamente al ámbito interpretativo sino que se extendió al ámbito docente (tal como se ha podido observar al estudiar los reglamentos de dicha capilla) como forma de transmisión de conocimientos musicales y de asegurar la continuidad de la propia capilla musical. En definitiva, con el fin completar nuestra visión de la música religiosa española de aquella época, sería necesario tener en cuenta no sólo la actividad de las capillas musicales catedralicias sino también la de las capillas pertenecientes a colegiatas o parroquias, que en el caso de la ciudad fronteriza de Irún ofrece un extraordinario interés.

\section{BIBLIOGRAFÍA}

ARANA, José Antonio, Música vasca, Bilbao, Caja de Ahorros Vizcaína, 1987.

BAGÜÉS, Jon, ANSORENA, José Luis, “Guipúzcoa”, Emilio CASARES (ed.), Diccionario de la Música Española e Hispanoamericana, Madrid, Sociedad General de Autores y Editores, 2000, vol. 6: 76-85.

BALENCIAGA, Santiago, "Erección de la primitiva parroquia de Irún”, Boletín de Estudios del Bidasoa (Irún, 1992): 229-260.

CAPDEPÓN, Paulino, "La música madrileña durante la Guerra de la Independencia: la canción patriótica", Anales del Instituto de Estudios Madrileños, 48 (Madrid, 2008): 131-148.

ELIZONDO, Esteban, La organería romántica en el País Vasco y Navarra (1856-1940), Barcelona, Universidad de Barcelona, 2001.

ELIZONDO, Esteban, “La organería romántica en el País Vasco y Navarra”, Nassarre: Revista aragonesa de musicología, 22-1 (Zaragoza, 2006): 121-130.

EXTRAMIANA, José, Historia de las guerras carlistas, San Sebastián, L. Haranburu, 1979.

JOVER ZAMORA, José María, Historia de España. Vol. XXXIV: La era isabelina y el Sexenio Democrático (1834-1874), Madrid, Espasa Calpe, 1988.

KEREXETA, Xabier: "Irún, ciudad fronteriza", http://www.alarde.org/a6/dimedeque/alardeas3.htm

LANDART, Esteban, Cavaillé-Coll. Irún, San Sebastián, Diputación Foral de Guipúzcoa y Kutxa, 2008. 
LEIÑENA, Pello, “Garmendia Aristimuño, Ramón”, Emilio CASARES (ed.), Diccionario de la Música Española e Hispanoamericana, Madrid, Sociedad General de Autores y Editores, 1999, vol. 5: 518.

LÓPEZ-CALO, José, P. LEGASPI, Rosana, “Aguayo Alonso, Cándido”, Emilio CASARES (ed.), Diccionario de la Música Española e Hispanoamericana, Madrid, Sociedad General de Autores y Editores, 1999, vol. 1: 102-103.

MARTÍN QUIÑNONES, María Ángeles, Joaquín Tadeo de Murguía (1759-1836). Organista de la Catedral de Málaga, Málaga, Universidad de Málaga, 1987.

Reglamento de la Capilla Música de la Iglesia Parroquial Santa María del Juncal y de la Música Marcial de la N. y L. M. B. y G. Villa de Irún, San Sebastián, Imprenta Tipo-litográfica de Pío Baroja, 1860.

Recibido: $15 / 10 / 2010$

Aceptado: 14/05/2012 
